\title{
The False Memory and the Effect of Murottal Al-Qur'an
}

\author{
Zulmi Ramdani, Ujam Jaenudin, Nani Nuranisah Djamal, Ari Anggara, Faridah Pertiwi, \\ Iyyah Syamsiyah, Muhammad Luthfi, Puput Juliana, Tri Wisda \\ UIN Sunan Gunung Djati Bandung \\ Corresponding Email: zulmiramdani@uinsgd.ac.id
}

\begin{abstract}
This study aims to see the effect of giving the Murottal Al-Qur'an to the decrease subject's level of false memory. Experimental design with post-test only control group design was used in this study. Participants involved in the study were 60 psychology students in the first semester by using random sampling. Participants grouped into an experimental group and a control group, each consisting of 30 participants. The instrument used was a false memory question comprising of 30 questions been validated by expert judgment at the trial stage. The instrument validation was carried out qualitatively by three lecturers with psychological and measurement backgrounds. Validation results show that there are language and content improvements in the instruments used, and then the authors correct them so that all experts agree that the instrument is suitable for use. Meanwhile, the results of the study show that there is a significant difference between the two groups given treatment and not, where from the score obtained, the experimental group obtained a greater score on filling in the false memory test than the control group. These studies inform that giving Murottal Al-Qur'an can reduce the level of false memory in the subject.
\end{abstract}

Keywords: False Memory, High Order Thinking, Murottal Al-Qur'an, Experiment, Word Analogy

\begin{tabular}{|c|c|c|c|c|}
\hline Submission & Review Process & Revised & Accepted & Published \\
\hline February 20, 2020 & $\begin{array}{c}\text { April 18, 2020- } \\
\text { May 5, 2021 }\end{array}$ & May 10, 2021 & May 20, 2021 & June 30, 2021 \\
\hline
\end{tabular}

\section{Introduction}

False memory is a memory of an event that never happened or a different memory from the actual event (Watson et al., 2004). On another utterance, it can be said that false memory is a distorted episodic memory. Episodic memory is memory related to events in the past (Sandrini et al., 2019).

Episodic memory stores information about the content, location, and face of an event so that it is very influential on human life (Hassabis \& Maguire, 2007; Rugg \& Vilberg, 2013). Human dependence on their memory makes them believe that memory must provide correct information. However, in reality, human memory can experience an error. This happens because human's memory is vulnerable to a lot of mixed information, can be lost, can be replaced, can even be created
(Leising et al., 2019). The results showed that real and false memories activate the same parts of the brain, processed by the same methods, and show the same patterns (Otgaar et al., 2019). Thus, we will find it difficult to distinguish which memory is true or false because both are experienced the same as real memory.

In Bhinnety (2008), there are two kinds of memory; Short Term Memory and Long Term Memory. The first appeared information entered in short-term memory, which always acts collectively with another because it directly related to knowledge. If the information already received in short memory, it can be retransfered through long-term repetitive activity so it can be stored, or the obtained information lost because of it has been replaced by something new (Ranganath 
\& Blumenfeld, 2005). Basically, humans have complex memories, because of those things, memory, either short or long term as a model and it is not an actual part of the brain (Sainath et al., 2015).

Several factors influence the formation of false memories. Roediger et al. (1996), states that the misinformation effect, is the effect of wrong information causing a person to recall. In addition, loading questions that use strong-meaning-words can also trigger a person to get false memories (Griffin et al., 2017; Lim \& Goh, 2019). Other studies have also shown that old adults are more likely to form false memories than young adults (Dennis \& Turney, 2018), Thus, age is suspected to influence a person to do false memory. These factors then create memory errors, starting from mistakenly in remembering vocabulary, wrong report for such event, to mistaken memories of important events in everyday life.

The author conducted a preliminary study that aims to strengthen the phenomenon that false memory actually occurs in the subjects studied. The activity carried out through an unstructured interview method to a random sample of 10 psychology students. Facts in the field show that there are errors (false memory) in students, one of which is when answering exam questions, especially if it done by using a true or false format. The concept of the problem is included in an objective test that is useful to see the extent of the output of learning, especially which related to the memory aspect. Another fact showed by Blank (2017), who states that there are many different examples of dissociation of beliefs and memories. This is what makes the memory of the problems faced by students tend to often experience false memories.

Concentration is a very important activity for each individual to be able to focus on an object, so that it can be understood easily. Concentration is often assumed as a condition when the mind gets an activation inside the body (Greenlees et al., 2006). This activation requires the body to be in relaxed and calm position. This will later make a person able to optimize his brain well (Nakamura \& Dubin, 2015). A pleasant atmosphere will be felt by someone when they are in a comfortable condition and do not feel that there is a threatening stimulus (Allen et al., 2013). Therefore, to get such calm and optimal conditions, we need the right method that can make the individual's mind more focus on an object that is memorized.

Music therapy is one of the effective methods used to stabilize the body and brain. Music therapy is a healing process that can reduce the pain and make the body of the subject more relaxing (Lee et al., 2005). Research describes that when the body is in a comfortable position to acquire appropriate music, it will make individuals solve problems and difficulties in the learning process (Raglio et al., 2020; Skeja, 2014). In addition, biologically, the design of music that is listened to by someone in a calm state can increase the release of endorphin hormones that function in reducing the effects of stress resulting from lecturing pressure. (He et al., 2019).

Music is an artistic instrument producing sound and contains various elements of melody and rhythm (Raharjo, 2007). In another form, music can be in chanting the Murottal Al-Qur'an form which significant and positive effect on someone's body (Aprilini et al., 2019). Murottal AlQur'an itself is in a voice recording form sung by someone. The result of chanting produces a human voice and can be a good healing media because it can reduce stress levels, activate relaxing hormones such as endorphins (increasing the relax feeling) (Aprilini et al., 2019). The evidences of the superiority of giving Murottal Al-Qur'an is shown by various previous studies, One of them is being able to 
increase the ability and individuals cognitive development, especially their memories become sharp (Aprilini et al., 2019; Fauziyyah et al., 2018; Lukmawati et al., 2018).

Listening to Murottal Al-Qur'an is also known to rise up the alpha waves, which can improve memory. Alpha waves will make relax the brain condition, but keep alert so the hippocampus as a memory center can work optimally (Supradewi, 2010). When the verses of the Al-Qur'an are heard, the human brain will experience waves increasing that function to growth memory capacity in digesting information into the body (Aris et al., 2019; Haslbeck et al., 2020; Silverman \& Bibb, 2018).

In Indonesia, there have been many related studies tried to make Murottal AlQur'an as a preventive or alternative media in increasing the body's organs capacity and ability. As done by Aprilini et al. (2019) where Murottal Al-Qur'an is proven effectively in reducing insomnia and strengthening individual self-regulation (Lukmawati et al., 2018). Then research related to the function of Murottal Al-Qur'an in reducing anxiety and academic stress (Ansyah et al., 2019; Yudhani et al., 2017). Fauziyyah et al. (2018), also explained that the method was able to improve a person's memory significantly. However, there has been no previous study has proven the relationship between Murottal Al-Qur'an and a decrease in subjects' false memory level. This is so important to do, considering that Murottal Al-Qur'an is routine activity that can be done anytime and even in free time. Meanwhile, false memory itself is a common phenomenon among students, especially if they are in an unstable emotionally. Therefore, this research is very important to do, where the author himself aims to determine the effect of giving Murottal Al-Qur'an in reducing on subject's false memory level. The researcher himself hypothesizes; the treatment given is able to reduce false memory in the subject (alternative hypothesis).

\section{Research Methods \\ The Research Design.}

This study uses a true experimental designed with a post-test only control group design (Furtak et al., 2012; Gersten et al., 2005). This design is dividing participants into two groups, which is selected by random sampling. Meanwhile, random assignment was also carried out to identify a more proportional division of the group by dividing the sex of each group equally also ensured that every individual have the same GPA when involved in research. The first group is the experimental group, the group that is given treatment $(\mathrm{X})$ during the phase of research and the other group is the control group, which acts as a waiting group during the core research phase. The control group in the study is as a comparison to the group that has been given treatment within a certain time (Furtak et al., 2012). For more details, see picture 1 (Experiment Scheme).

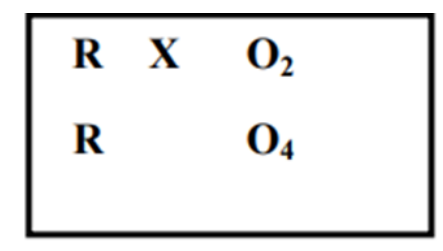

Picture 1. Experiment Scheme Post-test Only Control Group Design

The picture above describes the flow of the experiment in this study, where the $\mathrm{R}$ shows two groups selected randomly. The $\mathrm{X}$ symbol is the type of treatment given in the study, namely the provision of Murottal AlQur'an. While the O symbol indicates the final measurement result, where $\mathrm{O} 2$ is the post-test result of the experimental group and $\mathrm{O} 4$ is the post-test result of the control group.

The Research Subject. The population in this study were the first semester students at a psychology faculty at a state university in 
Bandung. Subject characteristics are determined based on preliminary studies that first semester students are in vulnerable condition to lecture problems (Ramdani et al., 2018). One of them is the problem in identifying the true or false question which is directly related to memory activity and the possibility of false memory. The sample was selected randomly and obtained 60 students who were divided into the control group and experimental group (30 people for each group). More specifically, the authors found the fact based on the early study that the majority of the studied subject population experienced the phenomenon of false memory which could be seen from the answers of their early studies about the condition. 60 people are selected from a list of subjects in the existing population using the random participant application. Then 60 subjects is selected with a note that they were willing to be actively involved in this study, as well as the existing research schedule according to their free time. Furthermore, the clustering process is carried out proportionally to divide into an experimental group and a control group.

\section{Measurement Instrument. The} measuring instrument used is a set of false memory tools containing a word list, which is divided into 3 contents; general content, psychological content, and Islamic content, each of consists of 15 words that have been validated by linguists and psychologists as three assessors. The results of the validation through three experts show that qualitatively there are several parts of the instrument used that have to improve and complete by the author. After complete completion, experts agree that the existing instrument is suitable to be used. The reference source for making the instrument is based on DRM (Deese-RoedigerMcDermott) which is a method for measuring memory accuracy with a list of directive words (Graham, 2007; Neuschatz, Benoit, \& Payne, 2003; Watson et al., 2004). These researchers also agree that this method can be used to look at possible memory errors that usually occur in a person in a simple way, although to be more complete one must use a set of sophisticated tools that are specifically designed biologically and psychologically.

General content is a group of words that have meaning for common events in the environment. The general content used in this study is mountain-related events. Psychological content is a group of words that have the meaning of events related to psychological material. In this study, psychological content related to schizophrenia is used. Islamic content is a group of words that have a meaning related to historical events of the Islamic religion. In Islamic content, this study uses content related to the events of the Battle of Badr. Instrument used when post-test false memory.

The instrument is given to the subject to be seen according to the specified time. Each subject will be given the opportunity to memorize the words in the existing manual book and then asked to choose or rewrite the words relevant to the problem provided. The correct and appropriate words and in accordance with the code of the book are given a score of 1 point while those that are wrong are left alone. At the end, each subject had a total score for them, which explained the strength of their memory to the false memory stimulus.

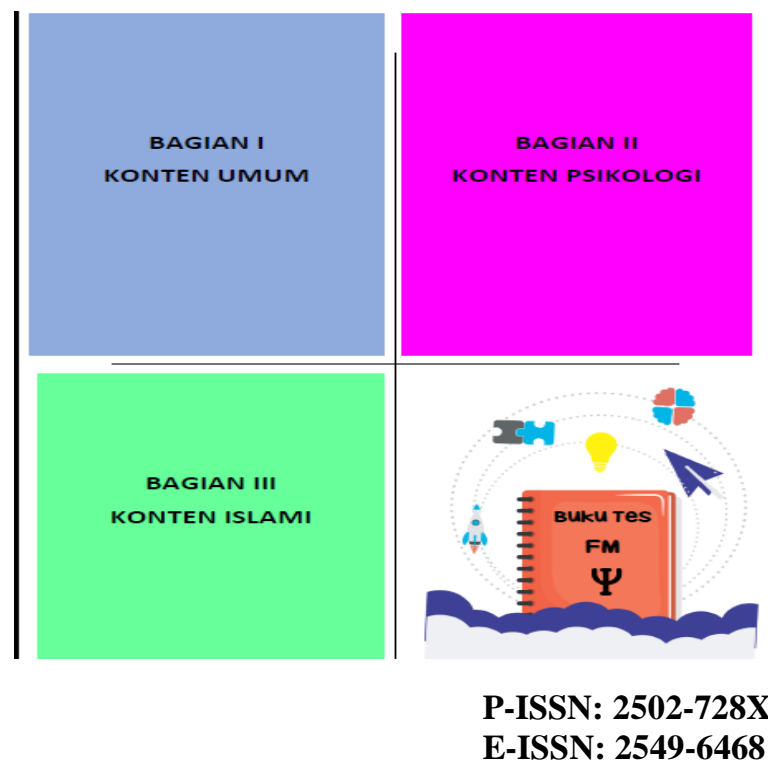


Picture 2. Instrument Cover False Memory (FM)

Table 1

False Memory Vocabulary List

\begin{tabular}{ccc}
\hline General & Psychological & Islamic \\
\hline Bukit & Mental & Quraisy \\
Lembah & Delusi & Badar \\
Mendaki & Halusinasi & Rasulullah \\
Puncak & Paranoid & Sahabat \\
Tebing & Suara-suara & Malaikat \\
Gundukan & Hasrat & 313 Orang \\
Magma & Emosi & Kuda \\
Polos & Bunuh Diri & Pedang \\
Gletser & Kacau & Jihad \\
Kambing & Otak & Al Liwa \\
Sepeda & Gen & Khazraj \\
Jarak & Obat & Ramadhan \\
Pendaki & Autoimun & Al-Anfal 9 \\
Curam & Oral & Muhajirin \\
Ski & Terapi & Abu Jahal \\
\hline
\end{tabular}

Experimental Procedure. This study began by dividing the participants into two groups: the experimental group and the control group. Each consist of 30 participant. Researchers gave treatment to the experimental group by listening to the Murrotal Al-Qur'an while memorizing a list of words in a false memory test book for 1 minute 25 seconds. The memorization time is modified and tested based on the analysis of the memorization sub-test (merkaufgaben) on Intelligenz Structure Test (IST) (Hakiki et al., 2018). The verse to be read is Surah AlBaqaroh verse 255 (Aprilini et al., 2019). Subjects in the control group did not get any treatment then the measurement is carried out again to see if there is a wrong memory through the answer sheet in true - false format (true or false).

Data Analysis. The research data will be analyzed using the normality test to ensure the obtaining data are normal and inferential analysis using Independent sample $t$ to test the comparison of the differences between the experimental group and the control group and determine whether the hypothesis is accepted or not (Warsihna et al., 2019). The researcher himself hypothesized that there was a significant differences between the two groups (alternative hypothesis)

\section{Results and Discussion}

The final score in the study was tested for normality first due to get data that is normally distributed (see table 2).

Table 2.

Normality Test Post-test Score

\begin{tabular}{lccc}
\hline \multirow{2}{*}{ Group } & \multicolumn{3}{c}{ Kolmogorov-Smirnov } \\
\cline { 2 - 4 } & Statistic & Df & Sig. \\
\hline Experiment & .153 & 30 & .072 \\
Control & .118 & 30 & .200 \\
\hline
\end{tabular}

Noted. Signifikan $(p>.05)$.

Referring to the results of normality in table 2, both scores in the experimental and control groups have a significance value above 0.05 so that both scores have a normal distribution of scores and theoretically further hypothesis analysis can be done.

Table 3.

Post-test Score Descriptive Results

\begin{tabular}{lcccc}
\multicolumn{5}{c}{ Post-test Score Descriptive Results } \\
\hline Group & $\mathrm{N}$ & Avarage & $\begin{array}{c}\text { Standard } \\
\text { Deviation }\end{array}$ & $\begin{array}{c}\text { Average } \\
\text { Standard } \\
\text { Error }\end{array}$ \\
\hline Experiment & 30 & 20.60 & 3.013 & .550 \\
Control & 30 & 17.93 & 5.152 & .941 \\
\hline
\end{tabular}

On table 3, information about descriptive result explained by giving the information that the score average got by the experimental group is higher (20.60) compared to average score got by control group (17.93).

Table 4.

T-Test Results

\begin{tabular}{lcccc}
\hline \multicolumn{5}{c}{ Levene's Test for Equality of Variance } \\
\hline & $\mathrm{F}$ & Sig. & $\mathrm{T}$ & $\mathrm{Df}$ \\
\hline Equal Variance & 7.568 & .008 & 2.447 & 58 \\
Assumed & & & & \\
Equal Variance & & & 2.447 & 46.754 \\
\hline
\end{tabular}

Noted. Signifikan $(p<.005)$.

Based on the data analysis results, the null hypothesis is rejected and the alternative hypothesis is accepted. According to the analysis using independent sample t-test, the significance level is .008 which means it is smaller than $.05(p<.05)$. Therefore, it can be concluded that Murrotal Al-Qur'an can reduce false memory in students. Based on the data analysis results (table 4), there is a difference between the control and experimental groups. 
In the experimental group, when treatment given, there was a decrease in false memory it can be seen from the results.

This research is supported by other relevant research by Aprilini et al. (2019) where Murrotal Al-Qur'an given to individual with a harmonious and slow tempo is able to effectively reduce negative hormones such as tension and stress further more can prevent individuals from those things. While other studies prove that with Murrotal Al-Qur'an, The condition of the individual's body can become more relaxed so that they are able to optimize the brain performance to be able to focus on facing the object (Fauziyyah et al., 2018). Not only useful for people who read it, but also Al-Qur'an can directly improve a person's ability to memorize and train their brain sharpness (Yudhani et al., 2017).

Murrotal is the right media, especially used to improve the learning process and get concentration on it. Lukmawati et al. (2018) said that a lot of glory is obtained by a person either when reciting the verses of the Qur'an or just by listening to them. When reciting the Murrotal Al-Qur'an is read with the appropriate tartil it will produce a wave effect that directly affects the state of the brain to be more positive and of course able to restore balance in the body and increase the capacity of human intelligence (Hojjati et al., 2014; Qolizadeh et al., 2019).

The effect of the Murrotal Al-Qur'an on the level of concentration in subjects can develop spatial memory, the existence of a good Murrotal Al-Qur'an stimulation on the activity of someone's brain performance. Focus is an important requirement that individuals use to view or evaluate an object and remember information. Due to the limited capacity of the human brain, then selective attention is very crucial to emerge information. Individuals who have mindfulness perform better on memory tests than individuals who have divided focus.
There are several things that support this research, namely conducive conditions, such as the placement of randomly selected groups so that there is no bias, air-conditioned room conditions, subjects were not allowed waiting too long before testing, as well as cell phone conditioning. These things can affect the effectiveness of a treatment for the subject (Ramdani, 2017). Apart from the technical aspect, the author realizes that the determination of the criteria for each group is limited to gender and GPA only. For further research, the authors will consider more comprehensively related to individual factors, both biological and psychological, before all individuals are involved in this experiment. Future research must reconsider the condition of the subject in a stable and proportional condition both in the experimental group and in the control group.

\section{Conclusion}

Giving Murrotal Al-Qur'an has a significant effect on decreasing the level of false memory in the subject. Giving Murottal Al-Qur'an has proven to be effective as a biological relaxation media in preventing the possibility of forgetting and increasing the power of memory so that they are more focused on doing something. Thus, this shows that Murrotal Al-Qur'an is effectively used in the learning process, especially those related to memorization activities.

\section{References}

Allen, M. S., Jones, M., McCarthy, P. J., Sheehan-Mansfield, S., \& Sheffield, D. (2013). Emotions correlate with perceived mental effort and concentration disruption in adult sport performers. European Journal of Sport Science, 13(6), 697-706. https://doi.org/10.1080/17461391.2013.7 71381

Ansyah, E. H., Muassamah, H., \& Hadi, C. 
(2019). Tadabbur surat al-insyirah untuk menurunkan stres akademik mahasiswa. Jurnal Psikologi Islam Dan Budaya, 2(1), 9-18.

https://doi.org/10.15575/jpib.v2i1.3949

Aprilini, M., Mansyur, A. Y., \& Ridfah, A. (2019). Efektivitas mendengarkan murottal Al-Qur'an dalam menurunkan tingkat insomnia pada mahasiswa. Psikis: Jurnal Psikologi Islami, 5(2), 146-154.

Aris, A., Sulaiman, S., \& Che Hasan, M. K. (2019). The influence of music therapy on mental well-being among postoperative patients of total knee arthroplasty (TKA). Enfermeria Clinica, 29(xx), 16-23. https://doi.org/10.1016/j.enfcli.2019.04.0 04

Bhinnety, M. (2008). Struktur dan proses memori. Buletin Psikologi, 16(2), 74-88. https://doi.org/10.22146/bpsi.7375

Blank, H. (2017). Recollection, belief and metacognition: A reality check. Memory, 25(7), 869-875. https://doi.org/10.1080/09658211.2016.1 238486

Dennis, N. A., \& Turney, I. C. (2018). The influence of perceptual similarity and individual differences on false memories in aging. Neurobiology of Aging, 62, 221230.

https://doi.org/10.1016/j.neurobiolaging. 2017.10.020

Fauziyyah, A., Ulfiah, U., \& Hidayat, I. N. (2018). Efektivitas metode tamyiz terhadap memori dalam mempelajari AlQur'an pada santri pondok pesantren Qur'an. Jurnal Psikologi Islam Dan Budaya, 1(1), 37-52. https://doi.org/10.15575/jpib.v1i1.2070

Furtak, E. M., Seidel, T., Iverson, H., \& Briggs, D. C. (2012). Experimental and quasi-experimental studies of inquirybased science teaching: A meta-analysis. Review of Educational Research, 82(3), 300-329. https://doi.org/10.3102/00346543124572 06

Gersten, R., Fuchs, L. S., Compton, D., Coyne, M., Greenwood, C., \& Innocenti, M. S. (2005). Quality indicators for group experimental and quasi-experimental research in special education. Exceptional Children, 71(2), 149-164. https://doi.org/10.1177/00144029050710 0202

Graham, L. M. (2007). Need for cognition and false memory in the Deese-RoedigerMcDermott paradigm. Personality and Individual Differences, 42(3), 409-418. https://doi.org/10.1016/j.paid.2006.07.01 2

Greenlees, I., Thelwell, R., \& Holder, T. (2006). Examining the efficacy of the concentration grid exercise as a concentration enhancement exercise. Psychology of Sport and Exercise, 7(1), 29-39.

https://doi.org/10.1016/j.psychsport.2005 .02 .001

Griffin, N. R., Fleck, C. R., Uitvlugt, M. G., Ravizza, S. M., \& Fenn, K. M. (2017). The tweeter matters: Factors that affect false memory from Twitter. Computers in Human Behavior, 77, 63-68. https://doi.org/10.1016/j.chb.2017.08.03 2

Hakiki, A. W., Fitri, A. R., \& Agung, I. M. (2018). Analisis properti psikometri subtes merkaufgaben (ME) dengan rasch model. Jurnal Psikologi, 14(1), 40. https://doi.org/10.24014/jp.v14i1.4900

Haslbeck, F. B., Jakab, A., Held, U., Bassler, D., Bucher, H.-U., \& Hagmann, C. (2020). Creative music therapy to promote brain function and brain structure in preterm infants: a randomized controlled pilot study. NeuroImage: Clinical, 102171. https://doi.org/10.1016/j.nicl.2020.10217 1 
Hassabis, D., \& Maguire, E. A. (2007). Deconstructing episodic memory with construction. Trends in Cognitive Sciences, 11(7), 299-306. https://doi.org/10.1016/j.tics.2007.05.00 1

He, S. C., Wu, S., Du, X. D., Jia, Q., Wang, C., Wu, F., ... Zhang, X. Y. (2019). Interactive effects of corticotropinreleasing hormone receptor 1 gene and work stress on burnout in medical professionals in a Chinese Han population. Journal of Affective Disorders, 252(December 2018), 1-8. https://doi.org/10.1016/j.jad.2019.03.084

Hojjati, A., Rahimi, A., Farehani, M. D., Sobhi-Gharamaleki, N., \& Alian, B. (2014). Effectiveness of Qur'an tune on memory in children. Procedia - Social and Behavioral Sciences, 114, 283-286. https://doi.org/10.1016/j.sbspro.2013.12. 699

Lee, O. K. A., Chung, Y. F., Chan, M. F., \& Chan, W. M. (2005). Music and its effect on the physiological responses and anxiety levels of patients receiving mechanical ventilation: A pilot study. Journal of Clinical Nursing, 14, 609-620. Retrieved from papers2://publication/uuid/82993B5CD823-41B6-9C73-31A99A95F11A

Leising, K., Jacqmain, J., Elliott, C., Wolf, J., Taylor, J., Cleland, L., ... Wright, A. A. (2019). Sensory and working memory in a spatial change-detection task by pigeons and humans. Behavioural Processes, 169(August), 103957. https://doi.org/10.1016/j.beproc.2019.10 3957

Lim, L. C. L., \& Goh, W. D. (2019). False recognition modality effects in short-term memory: Reversing the auditory advantage. Cognition, 193(June), 104008. https://doi.org/10.1016/j.cognition.2019.
104008

Lukmawati, L., Tanjung, F., \& Supriyanto, J. (2018). Al-qur'an itu menjaga diri: Peranan regulasi diri penghafal al-qur'an. Psikis: Jurnal Psikologi Islami, 3(2), 94. https://doi.org/10.19109/psikis.v3i3.1754 Nakamura, J., \& Dubin, M. (2015). Flow in motivational psychology. In International Encyclopedia of the Social \& Behavioral Sciences: Second Edition (Second Edi, Vol. 9). https://doi.org/10.1016/B978-008-097086-8.26088-1

Neuschatz, J. S., Benoit, G. E., \& Payne, D. G. (2003). Effective warnings in the DeeseRoediger-McDermott false-memory paradigm: The role of identifiability. Journal of Experimental Psychology: Learning Memory and Cognition, 29(1), 35-41. https://doi.org/10.1037/02787393.29.1.35

Otgaar, H., Bücken, C., Bogaard, G., Wade, K. A., Hopwood, A. R., Scoboria, A., \& Howe, M. L. (2019). Nonbelieved memories in the false memory archive. Journal of Applied Research in Memory and Cognition, 8(4), 429-438. https://doi.org/10.1016/j.jarmac.2019.07. 003

Qolizadeh, A., Myaneh, Z. T., \& Rashvand, F. (2019). Investigating the effect of listening to the Holy Qur'an on the physiological responses of neonates admitted to neonatal intensive care units: A pilot study. Advances in Integrative Medicine, 6(4), 159-162. https://doi.org/10.1016/j.aimed.2018.08. 004

Raglio, A., Imbriani, M., Imbriani, C., Baiardi, P., Manzoni, S., Gianotti, M., ... Manzoni, L. (2020). Machine learning techniques to predict the effectiveness of music therapy: A randomized controlled trial. Computer Methods and Programs in Biomedicine, 185, 105160. https://doi.org/10.1016/j.cmpb.2019.105 
160

Raharjo, E. (2007). Musik sebagai media terapi. Harmonia - Journal of Arts Research and Education, 8(3). https://doi.org/10.15294/harmonia.v8i3.7 72

Ramdani, Z. (2017). Hypertension information campaign community-based intervention design on students's knowledge and attitude improvement of hypertension potency. IJASOS-International E-Journal of Advances in Social Sciences, III(9), 850-858. Retrieved from http://ijasos.ocerintjournals.org

Ramdani, Z., Supriyatin, T., \& Susanti, S. (2018). Perumusan dan pengujian instrumen alat ukur kesabaran sebagai bentuk coping strategy. Jurnal Psikologi Islam Dan Budaya, 1(2), 97-106.

Ranganath, C., \& Blumenfeld, R. S. (2005). Doubts about double dissociations between short- and long-term memory. Trends in Cognitive Sciences, 9(8), 374380.

https://doi.org/10.1016/j.tics.2005.06.00 9

Roediger, H. L., Jacoby, J. D., \& McDermott, K. B. (1996). Misinformation effects in recall: Creating false memories through repeated retrieval. Journal of Memory and Language, 35(2), 300-318. https://doi.org/10.1006/jmla.1996.0017

Rugg, M. D., \& Vilberg, K. L. (2013). Brain networks underlying episodic memory retrieval. Current Opinion in Neurobiology, 23(2), 255-260. https://doi.org/10.1016/j.conb.2012.11.0 05

Sainath, T., Vinyals, O., Senior, A., \& Sak, H. (2015). Convolutional, long short-term memory, fully connected deep neural networks. ICASSP, 4580-4584. https://doi.org/10.1093/neuros/nyx387

Sandrini, M., Manenti, R., Gobbi, E., Rusich, D., Bartl, G., \& Cotelli, M. (2019).
Transcranial direct current stimulation applied after encoding facilitates 